\title{
Comparative anti-ulcerogenic activities of the leaf, seed and stem bark hydromethanolic extracts of Picralima nitida in rats
}

\author{
Maxwell I. Ezeja ${ }^{1 *}$, Kalu K. Igwe', Okezie V. Ikpeazu ${ }^{2}$
}

\author{
${ }^{1}$ College of Veterinary Medicine, Michael Okpara University of Agriculture, Umudike, Abia State, Nigeria \\ ${ }^{2}$ Department of Biochemistry, Abia State University, Uturu, Abia State, Nigeria
}

Received: 30 July 2020

Accepted: 01 September 2020

\author{
*Correspondence: \\ Maxwell I. Ezeja, \\ Email: maxwell.ezeja@gmail.com
}

Copyright: (C) the author(s), publisher and licensee Medip Academy. This is an open-access article distributed under the terms of the Creative Commons Attribution Non-Commercial License, which permits unrestricted non-commercial use, distribution, and reproduction in any medium, provided the original work is properly cited.

\begin{abstract}
Background: Picralima nitida (Stapf) commonly called akuamma belongs to the family apocynaceae found mostly in forest areas of Africa. It is a shrub or a deciduous tree that can grow up to 35 meters in height. It has a cylindrical trunk measuring about $60 \mathrm{~cm}$ in diameter with white latex in its parts. The bark of the trunk is fragile and is greyish brown or black in colour.

Methods: The acute oral toxicity test was done using up and down method. The anti-ulcerogenic activities of the leaf, seed and stem bark extracts were evaluated using ethanol-induced ulceration model in rats.

Results: There were no signs of morbidity and mortality in rats following oral acute toxicity test. The extracts produced a significant $(\mathrm{p}<0.05)$ dose dependent reduction in the number of ulcers and ulcer scores reducing them from $14.00 \pm 2.82$ and to $56.00 \pm 4.55$ to as low as $2.00 \pm 1.21$ and $8.45 \pm 1.24$ respectively. The ulcer preventive index was also increased by $P$. nitida extracts in a dose dependent manner with the (Picralima nitida leaf extract) PNLE at the dose of $400 \mathrm{mg} / \mathrm{kg}$ causing up to $76.13 \%$ inhibition of ulcers in the rats.

Conclusions: Picralima nitida extracts demonstrated significant anti-ulcerogenic activities in ethanol-induced gastric ulcerations in rats.
\end{abstract}

Keywords: Picralima nitida, Anti-ulcerogenic, Misoprostol, Ethanol-induced

\section{INTRODUCTION}

Ulcers can be defined as a conglomerate of heterogenous disorders which manifest as breaks in the lining of the gastrointestinal mucosa that might reflect in erosions and damage of the stomach wall that may become perforated. ${ }^{1}$ Peptic ulcer can also be defined as a discontinuity in the mucosa of the stomach and or the duodenum which often penetrate into the muscularis layer of the digestive tract. ${ }^{2}$

This is usually caused by impaired mucosal against the offensive factors of the gastrointestinal tract. ${ }^{3}$ Ulcers develop when the normal gastric equilibrium between the aggressive (acid and pepsin production and Helicobacter pylori) and protective mechanism (mucus and bicarbonate secretion, increased blood flow, cell turnover, permeability to $\mathrm{H}+$ etc) are disturbed by enhanced aggressive factors or reduced defensive factors or both. ${ }^{4}$

According to Khushtar et al, about $10 \%$ of the global population is affected and the annual new cases are is about four million annually and prevalence have shifted from have shifted from predominance in males to similar occurrence in both sexes while age group mostly affected are now increasingly older women and less frequently in younger men. 5,6

There is a variation of peptic ulcer symptoms which largely depends on the location of the ulcer or age of the person or animal affected. The most common symptom in man is epigastric pain causing burning and gnawing pain 
in the stomach and upper middle of the abdomen which can be relieved by eating or taking antacids. Others may include nausea and vomiting, appetite changes and unexplained weight loss among others. ${ }^{7}$

The main goals of treating peptic ulcers are normally to relieve pain, achieve ulcer healing and probably prevent ulcer reoccurrence. Drug treatment is at either counteracting the aggressive factors or stimulating mucosal defences. ${ }^{8}$ The most common drugs used for treatment of peptic ulcers include the use of $\mathrm{H} 2$ receptor antagonists, prostaglandin and its analogues, antacids, antibiotics etc. These drugs are associated with many side effects which include: headache, renal disorders, dry mouth, vomiting, diarrhoea, constipation etc. ${ }^{5}$

These side effects have led to for safer alternative therapies for management of ulcers and the most widely used alternatives are plant based product. ${ }^{2,9}$ Medicinal plants have been documented to have advantages in toxicity considerations based on their long term use and one might expect bioactive compounds obtained from such plants to have low animal and human toxicity. ${ }^{10}$

Picralima nitida (Stapf) commonly called akuamma belongs to the family known as apocynaceae. It is found mostly in forest areas of Africa such as ivory coast, uganda, cameroun, democratic Republic of congo, nigeria etc. ${ }^{11}$ The local names in some nigeria countries include: osi or osu-iwe in igbo; otosi in idoma and erin in Yoruba. It is a shrub or a deciduous tree that can grow up to 35 meters in height. It has a cylindrical trunk measuring about $60 \mathrm{~cm}$ in diameter with white latex in its parts. The bark of the trunk is fragile and is greyish brown or black in colour. The fruits are ovoid and yellowish when mature with each fruit containing three seeds which are covered in a pulp. The leaves are opposite, simple, entire and pinnately veined while the flowers are bisexual and regular. ${ }^{12}$

Various parts (leaves, fruits and stem bark) have been used in African ethnomedicine for the treatment of some ailments such as fever, hypertension, jaundice, dysmenorrhea, malaria and gastrointestinal disorders among others. ${ }^{13}$

Hence this study was undertaken to establish the pharmacological basis for the use $P$. nitida in folkloric medicine for the treatment of gastrointestinal disorders, peptic ulcers inclusive.

\section{METHODS}

Collection and identification of plant material fresh leaves, seeds and the stem bark of Picralima nitida were collected from Owerri in Imo State, Nigeria and identified by Prof. M.C. Dike, a taxonomist of the college of Natural and Environmental Sciences, Michael Okpara University of Agriculture, Umudike (MOUAU). A voucher specimen number MOUAU/VPP/2020/23 was deposited in the Department of Veterinary Physiology and Pharmacology, College of Veterinary Medicine, MOUAU herbarium.

\section{Extraction of plant material}

Extraction was done by cold maceration method. The leaves, seeds and stem bark were separately chopped into small pieces, dried under room temperature, pulverised into a coarse powder and macerated with $80 \%$ methanol for $48 \mathrm{hrs}$ with intermittent shaking at 2 hours internal. The respective extracts were filtered was concentrated in a hot air oven at $40^{\circ} \mathrm{C}$. The extracts were stored in a refrigerator at $4^{\circ} \mathrm{C}$ as PNLE, PNSE, PNBE for the leaf, seed and stem bark extracts respectively until time of use. The yield of the extract was calculated using the formula below.

$$
\frac{\text { Weight of extracted material }}{\text { Weight of starting material }} \times \frac{100}{1}
$$

\section{Experimental animals}

A total of 40 mature rats of mixed sexes weighing between 120-150 g obtained from the laboratory animal unit of the Department of Veterinary Physiology and Pharmacology, MOUAU were used for the experiment. They were housed in stainless still cages and fed with standard commercial pelleted feed (Vital feed®, Nigeria) while clean drinking provided ad libitum. Ethical conditions governing the conducts of experiments with life animals were strictly observed as stipulated by Ward and Esea. ${ }^{14}$

\section{Toxicity study}

The acute toxicity study was done using the up and down method as described by QECD15.

Effects of the leaf, seed and stem bark extracts of $P$. nitida on ethanol - induced gastric ulceration

Forty mature rats of mixed sexes were fasted for $24 \mathrm{hrs}$ with drinking water provided ad libitum. The rats were randomly assigned to 8 groups of 5 rats per group.

Group 1 rats (negative control) received $10 \mathrm{ml} / \mathrm{kg}$ distilled water, Group 2 rats (positive control) received $50 \mu \mathrm{g} / \mathrm{kg}$. Groups 3 and 4 received 200 and $400 \mathrm{mg} / \mathrm{kg}$ respectively of the leaf extract of $P$. nitida. Groups 5 and 6 received 200 and $400 \mathrm{mg} / \mathrm{kg}$ respectively of the seed extract of $P$. nitida. Groups 2 and 4 received 200 and 400 $\mathrm{mg} / \mathrm{kg}$ respectively of the seed extract of $P$. nitida while groups 7 and 8 received 200 and $400 \mathrm{mg} / \mathrm{kg}$ of the stem bark extract of $P$. nitida respectively, all by gastric gavage. One $\mathrm{hr}$ after these treatments, $1 \mathrm{ml}$ of absolute alcohol was administered to all the rats by gastric gavage. The rats were sacrificed $2 \mathrm{hrs}$ later by cervical dislocation. ${ }^{16}$ 


\section{Stomach processing and assessment of ulcers}

The abdomen of each of the rats was cut open. The stomach was isolated and cut open along the greater curvature, washed under running water and examined for ulcer lesions with the aid of a magnifying glass (X10). The ulcers were scored and the total number of ulcers, ulcer scores and ulcer index were obtained for each rat according to the method of main and Whitle17. The percentage preventive index was also calculated. ${ }^{18}$

\section{Histopathology}

Rat stomach sections collected after sacrifice of the rats were fixed in $10 \%$ formal saline for a minimum of $24 \mathrm{~h}$. They were washed in ascending grades of ethanol, cleared with xylene, embedded in paraffin wax, sectioned with a microtome and stained with haematoxylin and eosin $(\mathrm{H}$ and $\mathrm{E})$. All the sections were examined under a light microscope (X100). Photomicrographs of lesions were taken with an Olympus photo microscope. ${ }^{19}$

\section{Duration of data collection}

The duration of this study was 1 year, and ethical approval was taken from the university ethical committee, Informed consent form was taken from the patient, confidentiality of information and privacy were assured.

\section{Data analysis}

Data obtained was presented as Mean \pm Standard Error of Mean (SEM) and analysed using One Way Analysis of Variance (ANOVA). The variant means of the different groups were separated with Least Significant Difference (LSD). Significance was accepted at $\mathrm{p}<0.05$.

\section{RESULTS}

\section{Yield of the extract}

The percentage yield of the extract was $9.85 \% \mathrm{w} / \mathrm{w}$ dry that was dark brown in colour.

\section{Acute toxicity test}

The leaf, seed and stem bark extracts of $P$. nitida were well tolerated as the animals did not show any signs of morbidity and there was no mortality observed.

\section{Ethanol induced gastric ulceration in rats}

P. nitida (leaf, seed and stem bark) extracts produced a significant $(\mathrm{p}<0.05)$ dose dependent reduction in the number of ulcers and ulcer scores reducing them from $14.00 \pm 2.82$ and to $56.00 \pm 4.55$ to as low as $2.00 \pm 1.21$ and $8.45 \pm 1.24$ respectively.

The ulcer preventive index was also increased by $P$. nitida extracts in a dose dependent manner with the PNLE at the dose of $400 \mathrm{mg} / \mathrm{kg}$ causing up to $76.13 \%$ inhibition of ulcers in the rats. The results also showed that the extracts at the doses of $400 \mathrm{mg} / \mathrm{kg}$ showed better inhibition effects than the doses of $200 \mathrm{mg} / \mathrm{kg}$ for the leaf and seed extracts. There was no significant difference in activity between $200 \mathrm{mg} / \mathrm{kg}$ and $400 \mathrm{mg} / \mathrm{kg}$ doses of the stem bark extract (Table 1).

The ulcer index was also significantly $(\mathrm{P}<0.05)$ reduced dose dependently except by the PNLE at the dose of 200 $\mathrm{mg} / \mathrm{kg}$ where the reduction was not statistically significant (Figure 1).

Table 2: Effect of $\boldsymbol{A}$. nitida extracts on ethanol-induced ulceration in rats.

\begin{tabular}{|c|c|c|c|c|}
\hline Group & Treatment & No of ulcers \pm SEM & $\begin{array}{l}\text { Ulcer score } \\
( \pm \text { SEM) }\end{array}$ & $\begin{array}{l}\text { Preventive index } \\
(\%)\end{array}$ \\
\hline 1 & Distilled water $10 \mathrm{ml} / \mathrm{kg}$ & $14.00 \pm 2.82$ & $56.00 \pm 4.55$ & 0.00 \\
\hline 2 & Misoprostol $50 \mu \mathrm{g} / \mathrm{kg}$ & $2.25 \pm 0.67 *$ & $9.15 \pm 3.42 *$ & 55.40 \\
\hline 3 & ANLE $200 \mathrm{mg} / \mathrm{kg}$ & $5.75 \pm 2.22 *$ & $23.20 \pm 3.66^{*}$ & 14.20 \\
\hline 4 & ANLE $400 \mathrm{mg} / \mathrm{kg}$ & $2.25 \pm 0.99 *$ & $9.55 \pm 1.30 *$ & 76.13 \\
\hline 5 & ANSE $200 \mathrm{mg} / \mathrm{kg}$ & $3.00 \pm 0.55^{*}$ & $12.20 \pm 0.80 *$ & 43.82 \\
\hline 6 & ANSE $400 \mathrm{mg} / \mathrm{kg}$ & $2.00 \pm 1.21^{*}$ & $8.45 \pm 1.24 *$ & 66.67 \\
\hline 7 & ANBE $200 \mathrm{mg} / \mathrm{kg}$ & $3.75 \pm 0.77^{*}$ & $11.11 \pm 2.49 *$ & 54.73 \\
\hline 8 & ANBE $400 \mathrm{mg} / \mathrm{kg}$ & $3.15 \pm 2.15^{*}$ & $19.25 \pm 2.30 *$ & 55.55 \\
\hline$* \mathrm{P}<$ & ANLE $=\quad$ Picralima & leaf extract, & $=\quad$ Picralima & seed \\
\hline
\end{tabular}

ANBE $=$ Picralima nitida stem bark extract.

\section{Histopathology}

The result of the histopathological evaluation of stomach sections of rats treated with $P$. nitida extracts, distilled water and misoprostol is presented in (Figure 2) The distilled water treated showed deep ulceration of the rats' stomach that affected both the mucosa and submucosa extending even to the muscularis externa (Group 1). In groups 3 , there was adverse ulceration of the mucosa with considerable erosion limited to the mucosa while in groups 2, 4, 6, 7 and 8, misoprostol and the extracts showed varying levels of protection which in mild to nonobservable ulcerations with the highest protection seen in group 4 (PNLE $400 \mathrm{mg} / \mathrm{kg}$ ). 


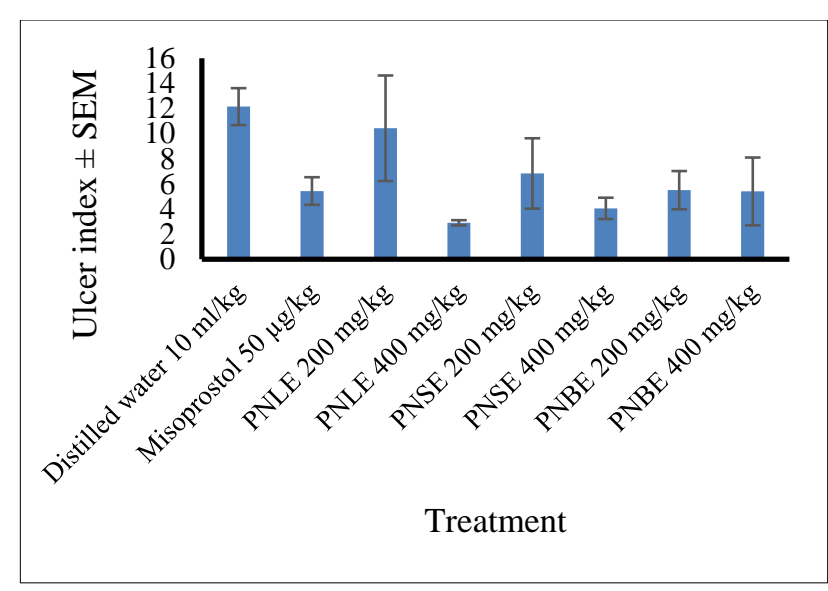

Figure 1: The ulcer index of extracts
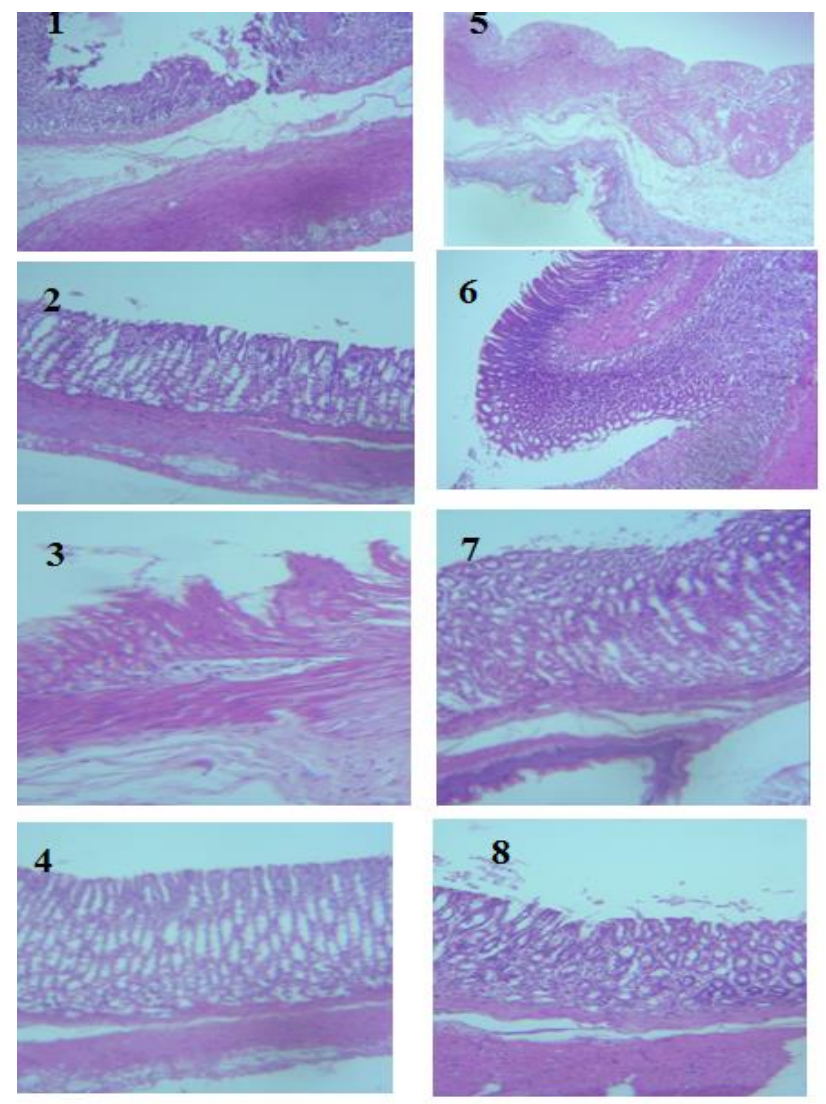

Figure 2: Plate 1. Histopathological sections (H\& E X 100) of stomachs of ethanol-induced gastric ulcers in rats.

Legend: Arrow shows areas of severe ulceration. $1=$ Distilled water; 2 =Misoprostol $(50 \mathrm{~g} / \mathrm{kg}) ; 3=$ PNLE $(200 \mathrm{mg} / \mathrm{kg})$; 4=PNLE $(400 \mathrm{mg} / \mathrm{kg}) ; 5=P N S E(200 \mathrm{mg} / \mathrm{kg}) ; 6=$ PNSE $(400$ $\mathrm{mg} / \mathrm{kg}), 7=\mathrm{PNBE}(200 \mathrm{mg} / \mathrm{kg}) ; 8=\mathrm{PNBE}(400 \mathrm{mg} / \mathrm{kg} . \mathrm{cts})$

\section{DISCUSSION}

The leaf, seed and stem bark extracts of Picralima nitida were evaluated for their anti-ulcerogenic activities using ethanol-induced gastric ulceration in rat model.
Ethanol causes disturbances in gastric secretion, damage to mucosa, gastric mucus depletion and free radical production. ${ }^{20}$ It also induces gastric lesions through stimulating lipid peroxidation, supressing prostaglandin production and reducing catalase, suproxide dismutase (SOD) and glutathione levels. Ethanol also causes cell death and exfoliation of gastric mucosa via increased membrane permeability to sodium and water and down regulating bicarbonate secretion consequently depleting protective mucus, exposing gastric mucosa to the destructive effects of pepsin and hydrochloric acid leading to gastric ulceration. ${ }^{21}$

Administration of absolute alcohol produced ulcer lesions on the glandular parts of the stomach which was most pronounced in the distilled water treated group.

The extracts of $P$. nitida showed significant inhibitory effect on ethanol-induced ulceration by dose dependently decreasing the ulcer parameters (number of ulcers, ulcer scores and ulcer index) and also increasing the ulcer preventive index. Also, the ulcer index which expresses the degree and severity of ulcers was significantly reduced by the extracts in a dose-dependent manner signifying the efficacy of $P$. nitida as anti-ulcer agent. The effects of the extracts were comparable to the standard drug (misoprostol) with the leaf extract even causing more protective effect than the drug.

Also, the gastroprotective effects of $P$. nitida was confirmed through the histopathological evaluation where the damage to the stomach layer was more evident in the distilled water treated group with varying degrees of protection in the extracts treated groups.

Picralima nitida extract may have protected the rats' stomach through the inhibition of mechanisms by which ethanol induces ulcers in rats as enumerated above or generally due to cytoprotection..$^{22}$

Potent antioxidant activity of $P$. nitida has been reported while the phytochemical analysis showed it contains alkaloid, flavonoids, tannins saponins and sterols. ${ }^{23}$ Antioxidant effects is considered as one of the main antiulcer mechanisms of medicinal plants through the inhibition of production of reactive oxygen species (ROS), scavenging of free radicals and enhancing membrane stability. ${ }^{24} P$. nitida may have acted through these means.

The anti-ulcerogenic effect of alkaloids results from ability to reduce gastric acid secretion, increase the $\mathrm{pH}$ of gastric contents and protect the mucous membrane membrane. ${ }^{25}$

Flavonoids has been reported to protect the gastric mucosal lesions in various experimental models. ${ }^{26}$ Flavonoids also protect the gastric mucosa from ulcerative and erosion lesions by increasing the mucosal 
prostaglandin content and also by its free radical scavenging ability. ${ }^{27}$

Tannins have also been reported to protect the stomach mucosa by producing layers over the gut lining by precipitating micro proteins at ulcerative sites thereby inhibiting GIT secretions and providing protection to GIT mucosa from irritants. ${ }^{28}$

From the above facts on alkaloids, flavonoids and tannins, the gastroprotective activity of the $P$. nitida extracts may be as a result of its phytochemical constituents.

The highest anti-ulcer activity of the plant was observed in the leaf extract $(400 \mathrm{mg} / \mathrm{kg})$. This suggests that there is likely to be more concentration of the active principle and/or phytochemical components responsible for the anti-ulcer in the leaves when compared to other parts.

\section{CONCLUSION}

Picralima nitida extracts demonstrated significant antiulcerogenic activities in ethanol-induced gastric ulcerations in rats with the highest activity seen in the leaf extract and these activities may have been mediated through cytoprotection, antisecretory and antioxidant mechanisms and/or through the phytochemical constituents of the plant. However, further studies are needed to isolate the active principle responsible for antiulcer activity and also to determine the exact mechanism of action.

\section{Funding: No funding sources \\ Conflict of interest: None declared \\ Ethical approval: Not required}

\section{REFERENCES}

1. Wallace JL. Prostaglandins, NSAIDs and gastric mucosal protection: why doesn't stomach digest itself. Physiol Rev. 2008; 88:1547-65.

2. Singh AK, Singh Sk, Singh PP, Srivastava AK, Pandey KA, Kumar A, Yandev H. Biotechnological aspects of plants metabolites in the treatment of ulcers: A review. Prospective Biotechnol Rep. 2018.

3. Haung X, Sun X, Yu X, Qian H, Efficacy and safety of sijunzi decoction for peptic ulcersin a systemic review and meta -analysis. J Tradit Chinese Med Sci. 2018.

4. Babarstefano V, Cola M, Luiz-Feriera A, Farias-Silva E, Hiruma-Lima CA, Rinaldo D, Vilegas W, Souza B. Vernonia polyarithes as a new source of anti-ulcer drugs. Fitoterapia. 2007;78:545-51.

5. Khushtar M, Siddiqui HH, Dixit RK, Khan MS, Iqbal D, Rahman MA. Amelioration of gastric ulcers using a hydroalcoholic extract of Triphala in indomethacininducedwistar rats. Eur J. Integr Med. 2016;(8): 546-51.

6. Tri H, George TH. Peptic ulcer disease. In: medicine 2007.
7. Vyawahere NS, Desmukh VV, Godkari MR, Kagathara VG. Plants with anti-ulcer activity. Pharmacognosy Rev. 2009;108-15.

8. Gadekar R, Singour PK, Chaurasiya PK, Pawar RS, Patil UK. A potential of some medicinal plants as an anti-ulcer agent. Pharmagn Rev. 2010;(8):136-46.

9. Li Q, Yang L, Fan L, liang C, Wang Q, Wen H, et al. Activity of Brucea javanica oil emulsion against gastric ulcers in rodents 2018;13:279-88.

10. Fabricant and Fansworth NR. The value of plants used in traditional medicine for drug discovery. Environ Health Persp Suppl. 2001;109(1):67-76.

11. Burkill HM. The useful plants of West tropical Africa. Families A-D. Royal Botanical gardens. 2nd ed. United Kingdom, Kew Richmond: 1985;(1):960.

12. Adjanohoun JE, Aboubakar N, Dimante K, Ebot ME, Enow-orok Eg, Facho D, Traditional and pharmacopoeia technical and research commission of Organisation of African unity (OAU/STRC). 1996;60-1. Available at: www.au.int.

13. Osayemwenre E, Aiodun F, Peter L. Medicinal uses, phytochemistry and pharmacology of Picralima nitida (Apocynaceae) in tropical diseases: a review. Asian paci J Trop Med. 2014;7(1):1-8.

14. Ward JW, Elsea JR. Animal case and use in drug fate and metabolism. Methods and techniques. 2nd edition. New York, Mercel Deker: 1997.

15. OECD. Acute oral toxicity. Up and down procedure. Guideline for the testing of chemicals, 425, OECD 2018;1-2.

16. Sahoo Sk, Sahoo HB, Priyadarshini D, Soundarya G, Kumar CK, Rani KU. Anti-ulcer activity of ethanolic extract of Savadora indica (W) leaves on albino rats. J Clin Diagn Res. 2016;10(9):FF07-10.

17. Main HM, Whitle BR. The effects of $E$ and $A$ prostaglandins on gastric mucosal blood flow and acid secretion in rats. Brit J Pharmacol. 1975;53: 217-24.

18. Hano J, Bugajski J, Danek L, Wautuch L. The effects of neuroleptics on development of gastric ulcer in rats in exposed to restrint/cold stress. Pol $\mathbf{J}$ Pharmacol. 1976;288:37.

19. Bancroft JD, Stevens A. Theory and practice of histological techniques. 1st edition. USA, WB Saunders: 1977:223-66.

20. Salim AS. Removing oxygen derived free radicals stimulates healing of ethanol- induced erosive gastritis in the rats. Digest. 1990;47:24-8.

21. Adinorty MB, Ansah C, Galyuon I, Nyako A. In vivo models used for evaluation of potential anti gastroduodenal ulcer agents 2013.

22. Raju D, Ilango K, Chitra V, Ashish K. Evaluation of anti-ulcer activity of methanolic extract Terminalia chebula fruits in experimental rats. J Pharm Sci Res. 2009;1(3):101-7.

23. Naigissona P, Nkounkou LC, Namkona FA, Koane JN, Goully T, Syssa-Magale JL, et al. Phytochemical screening and evaluation of the antioxidant activity of polar extracts of Stapf. (Apocynnaceae) family. J Pharmacog. 2016;5(4):198-204. 
24. Shams-Ardekani MR, Rahami R. Five Pistacia species (P. vera, P; terebinthus, P. atlantica, P. khinjuk and $P$. lentiscus): A review of their traditional uses, phytochemistry and pharmacology. Scienti world J. 2013

25. La Cassa C, Villegas I, Alarcon DL, Motilva V, Calero MM. Evidence for protective and antioxidant properties of rutin, a natural flavone against ethanolinduced gastric lesions. J Ethnophamacol. 2000;71(12):45-53.

26. Zayachkivska OS, Konturek SJ, Drozdowicz D, Konturek PC, Brzowski T, Ghegotsky MR. gastro protective effects of flavonoids in plants extracts. J Physiol Pharmacol. 2005;56:216-31.
27. Borelli F, Izzo AA. The plant kingdom as source of anti-ulcer remedies. Phytother Res. 2000;14:581-91.

28. Dashputre NI, Naikwade NS. Evaluation of anti-ulcer activity of methanolic extract of Abutilon indicum Linn leaves in experimental rats. Intl J. of Pharm Sci and Drug Res. 2011;3(2):97-100.

Cite this article as: Ezeja MI, Igwe KK, Ikpeazu OV. Comparative anti-ulcerogenic activities of the leaf, seed and stem bark hydromethanolic extracts of Picralima nitida in rats. Int $\mathrm{J}$ Basic Clin Pharmacol. 2020;9:1485-90. 